\title{
Od krále k maršálovi. Závěr styků československé exilové vlády s královskou exilovou vládou Jugoslávie a počátky její spolupráce s hnutím J. B. Tita v letech 1943-1945
}

From the King to the Marshal. The Epilogue of Contacts of Czechoslovak Government-in-Exile with the Royal Government-in-Exile of Yugoslavia and the Beginnings of Its Cooperation with a Movement of J. B. Tito in 1943-1945

Jonáš Pospíchal / 361161@mail.muni.cz Historický ústav, Filozofická fakulta, Masarykova univerzita, Brno, CZ

\begin{abstract}
This text captures one the lesser-described epizodes of relations between Czechoslovakia and Yugoslavia, i. e. the relations of these countries during the World War Two. Since 1943, agile Partyzans have become the main Yugoslav political current that the Czechoslovak exile government has dealed with and was considered by it to be competent to rule the postwar Yugoslavia. The Czechoslovaks have done so at the expense of relations with the exile régime headed by the king Petar II. In this paper, I describe the transfer of Czechoslovak focus from the exile government to the homeland-based Partyzans. An analysis of causes, context and consequences of this Czechoslovak policy is also included.
\end{abstract}

\section{Keywords}

Czechoslovakia; Yugoslavia; World War Two; Exile; Partyzans 
Historie druhé světové války v Jugoslávii je nejčastěji vykládána jako příběh okupace země a zápasu četniků a partyzánů. Jde o dějiny bitev, strádání, boje všech proti všem, o dějiny fyzické destrukce. $\mathrm{V}$ hlavních rolích těchto příběhů tak stojí jména jako Dragoljub Mihailović, ${ }^{1}$ Josip Broz Tito, ${ }^{2}$ Ante Pavelić či Milan Nedić. Při popisu zničující okupace a občanské války v Jugoslávii však nelze vynechat oficiální vládu země v exilu, která byla protiněmeckými spojenci uznávána za oficiálního reprezentanta země. Stranou ikonických válčišt na Balkáně se královská jugoslávská exilová vláda snažila o zaujetí podobné role jako její československý protějšek - zastupovat svou zemi, koordinovat její osvobození a uchopit posléze moc na jejím teritoriu. Na rozdíl od Čechoslováků však exiloví Jugoslávci neuspěli a namísto krále Petra II. Karađorđeviće ${ }^{3}$ slavil v Bělehradě válečný triumf maršál J. B. Tito.

Od 29. listopadu 1943, kdy tento komunistický vůdce vznesl skrze své hnutí nárok na vládu v zemi, byli jugoslávští spojenci definitivně postaveni před realitu dvou uchazečů o poválečnou vládu. Spojené státy, Sovětský svaz i Velká Británie se snažily působit k usmíření domácí i exilové vlády v takové formě, která zajistí poválečný mír. Moc partyzánů však byla taková, že exilovým politikům zbyla pouze role druhých houslí v komunisty vedených státních institucích. Byla to však cena, kterou země protihitlerovské země byly připraveny zaplatit za zachování státní jednoty a národnostního smíru Jugoslávie.

1 Mihailović, Dragoljub (Draža), 1893-1946. Jugoslávský (srbský) voják. Účastnil se balkánských válek i první světové války a ve své armádní službě pokračoval jako profesionál i ve 20. a 30. letech. Sloužil, mimo jiné, v letech 1936-1937 jako vojenský atašé v Československu. Byl jedním z proponentů nadřízenými kritizovaného záměru přípravy válečné strategie založené na guerillových bojích v hornatém centru země. Tuto strategii nicméně na vlastní pěst úspěšně rozvinul za druhé světové války, kdy pod sebou shromáždil množství bojovníků královské armády, která oficiálně kapitulovala po několika dnech odporu útoku Osy v dubnu 1941. Byl jmenován ministrem vojska, námořnictva a letectva. Tvořil překážku dohodě exilové vlády s hnutím partyzánů a v létě 1944 tak již nebyl přizván do nové vlády a následně byl penzionován. Nová jugoslávská státní moc jej stíhala a v březnu 1946 také dopadla. Dne 17. července 1946 byl popraven zastřelením.

2 Tito, Josip Broz, 1892-1980. Jugoslávský (chorvatský) politik a voják. Pocházel ze smíšeného chorvatsko-slovinského prostředí, pracoval jako mechanik, bojoval v první světové válce, kde padl do zajetí. V ruské občanské válce bojoval na straně bolševiků, jejichž ideologii přijal. Po válce přijel do Jugoslávie, kde se stal jedním z organizátorů tamější komunistické strany a záhy s ní přešel do ilegality. Byl vězněn a jinak perzekvován. V roce 1939 byl Kominternou prosazen na pozici generálního tajemníka Komunistické strany Jugoslávie. Za druhé světové války zorganizoval úspěšné hnutí komunisty vedených bojovníků, partyzánů. V závěru války dospěl k dohodě s exilovou vládou, která splynula s vrcholnými partyzánskými správními tělesy. Po válce se stal ministerským předsedou a prezidentem Jugoslávie. Ta se pod vládou jím vedené komunistické strany stala komunistickou zemí organizovanou na federálním základě. Po roztržce se Sovětským svazem (vyvolané Titovou neochotou podřídit zájmy a prestiž své země politickým potřebám SSSR), k níž došlo v průběhu roku 1948, se stal terčem propagandy východního bloku. Po normalizaci vztahů se Sověty v roce 1956 a jejich satelity se zasazoval o vytvoření nezávislého bloku států mimo bipolární svět (Hnutí nezúčastněných zemí). Své vedoucí postavení v zemi si uchoval až do své smrti.

3 Karađorđević, Petar II., 1923-1970. Jugoslávský princ a následník trůnu po smrti svého otce v roce 1934. Vzděláván byl v Británii, po atentátu na svého otce se vrátil do země, a jakožto nezletilému mu byli ustanoveni regenti, krom dvou politiků to byl Pavle Karađorđević. V převratu dne 27. března 1941 se formálně chopil moci. V exilu pokračoval dále ve svém vzdělávání v Oxfordu, vstoupil do britských vzdušných sil. Nebyl politicky příliš aktivní. V exilu se oženil s Alexandrou, řeckou princeznou. V závěru války mu bylo zabráněno v návratu do země do doby poválečného rozhodnutí lidu v této věci. Dne 29. listopadu 1945 byl definitivně detronizován. Zůstal v emigraci, kde se mu také narodil jeho syn Aleksandar. Zemřel v Denveru v USA. V roce 2013 byly jeho ostatky uloženy do královské hrobky v Oplenci v srbské Šumadiji. 
Také Československo se v průběhu let 1943-1945 rozhodlo nebojovat předem prohraný boj za dosavadní politiky a vsadit na spolupráci s hnutím J. B. Tita.

Jak vypadaly vztahy československé a jugoslávské exilové vlády do doby, než došlo k podpoře partyzánů? Jaké byly důležité momenty v této změně politické linie? Jakou podobu měly první kontakty exilových Čechoslováků a kdy k nim došlo? Existovaly naopak kontakty s královskou vládou i poté, co byla Čechoslováky opuštěna?

Odpovědět na tyto výzkumné otázky se pokouší následující text. Pramennou základnu tvoří ucelený soubor úředních pramenů československé (a v menší míře i jugoslávské) provenience, dále několik pramenů osobní povahy v podobě deníkových záznamů, a dodatečně také dobový periodický tisk. Tato stat̉ se dále opírá o českou i zahraniční sekundární literaturu. Při zpracování těchto zdrojů byla použita přímá a nepřímá metoda výzkumu a jejich výsledek se řadí mezi práce z oboru politických dějin.

\section{Jugoslávská vláda v exilu a její styky s exilovou vládou Československa 1941-1943}

Poměr exilové vlády Československa k jejímu jugoslávskému souputníkovi byl značně problematický dlouho předtím, než se v okupované Jugoslávii v listopadu 1943 ustavilo konkurenční partyzánské mocenské centrum. Samotná pozice této vlády byla komplikovaná od chvíle, kdy Jugoslávie rozmnožila řady exilových státních těles v květnu 1941 poté, co byla poražena během krátké, tzv. dubnové války. S sebou si politicky různorodá královská vláda nesla celou řadu obtížně řešitelných sporů, jejichž původ ležel v problémech meziválečného jihoslovanského státu. Jugoslávská politická scéna byla po celé meziválečné období parcelována spory mezi politiky smýšlejícími liberálně a tradičně, mezi centralisty a federalisty, př́ípadně i konflikty s okrajovými, mimo zákon stojícími skupinami, jako byli ultranacionalističtí chorvatští Ustašovci či komunisté. ${ }^{4}$ Všechny tyto problémy však v nebezpečnosti překonávaly národnostně motivované politické rozpory, které se s výše zmíněnými konflikty prolínaly a doplňovaly. Kromě celé řady jiných obtíží, které s sebou přinášely emancipační snahy obyvatelstva Makedonie, napětí mezi srbským a albánským obyvatelstvem na území Kosova a Metochie či aspirace mad’arského a německého obyvatelstva na severu země, byly nejvýraznějšími spory ony srbsko-chorvatské. Představovaly hrozbu pro samotnou soudržnost meziválečné Jugoslávie jako státu. ${ }^{5}$ V době bezprostředně předválečné bylo dosaženo jistého uvolnění tohoto napětí, když jugoslávská vláda slevila ze svého centralismu a vyšla vstříc chorvatské státoprávní emancipaci. Dohoda z 26. srpna 1939 mezi ministerským předsedou Dragišou Cvetkovićem

4 K meziválečnému Království Srbů, Chorvatů a Slovinců (od r. 1929 Království Jugoslávie) srov. zejména následující literaturu: Djilas, Aleksa: The contested country. Yugoslav unity and Communist Revolution 19191953. Harvard 1996; Krizman, Bogdan: Vanjska politika jugoslavenske države 1918-1941. Diplomatsko-historijski pregled. Zagreb 1975; Křen, Jan: Dvě stoleti středni Evropy. Praha 2005; Pelikán, Jan - Havlíková, Lubomíra - Chrobák, Tomáš - Rychlík, Jan - Tejchman, Miroslav - Vojtěchovský, Ondřej: Dějiny Srbska. Praha 2005 či Pirjevec, Jože: Jugoslávie 1918-1992. Vznik, vývoj a rozpad Karadjodjevićovy a Titovy Jugoslávie. Praha 2000.

5 Djilas, A.: The contested country, s. 140. 
a předsedou Chorvatské rolnické strany, vedoucím chorvatským politikem a následně místopředsedou Cvetkovićovy vlády Vladimirem (Vlatko) Mačkem6 (zvaná i v československém prostředí podle srbochorvatského názvu pro dohodu „Sporazum“) garantovala autonomní postavení Chorvatské bánovině, útvaru vzniklému spojením dvou menších administrativních celků s totožným jménem, v němž převažovalo chorvatské obyvatelstvo.

Kromě nemalého množství domácích problémů se Jugoslávie potýkala s obtížnou mezinárodněpolitickou situací. V průběhu 30. let se tato země, podobně jako i její balkánští sousedé, stávala ekonomicky stále více a více závislejší na Německu. ${ }^{7}$ Tato závislost byla od poloviny dekády doplněna také politickými ústupky vůči Německu, proti němuž Jugoslávie odmítala podpořit svého spojence v primárně protimad’arské Malé dohodě Československo. Ve spojení s dalšími jugoslávskými politickými kroky ${ }^{8}$ byla tato zahraniční politika Jugoslávie krajně nepříznivá pro Čechoslováky. Jugoslávii nicméně umožnila přetrvat první dva roky druhé světové války v míru a v neutrálním postavení vůči všem válčícím stranám. Na jaře 1941 však, v souvislosti s italskými a britskými akcemi na Balkánském poloostrově, spěla křehká jugoslávská neutralita ke konci. Po Mad’arsku, Rumunsku a Bulharsku, země, které k Německem vedenému Paktu tří přistoupily v závěru roku 1940 a na začátku roku následujícího, byla také Jugoslávie vyzvána k tomuto kroku, který znamenal oficiální vstup do mocenské sféry Německa. Bez reálných vyhlídek na účinnou pomoc Británie nakonec jugoslávská vláda dne 25. března 1941 uposlechla, což vyvolalo ostrou reakci prozápadních, zejména srbských politických a vojenských kruhů. Dne 27. března 1941 byla známým převratem svržena vláda a na místo svého strýce, regenta Pavleho Karađorđeviće,${ }^{9}$ který symbolizoval politiku podléhání Německu, nastoupil tehdy sedmnáctiletý Petar II. Karađorđević. Nová vláda složená s prozápadních, ale také pro Němce přijatelných politiků se snažila vydávat převrat za jugoslávskou vnitřní záležitost, která neovlivňuje její mezinárodní závazky, ani postoj k Velkoněmecké říši. Pučem rozzuřený Adolf Hitler odpověděl přepadením Jugoslávie bez vyhlášení války. K této akci se připojilo také Mad’arsko, Bulharsko a Itálie. Části jugoslávského území

6 Vladimir (Vladko, př́padně Vlatko) Maček (1879-1964). Jugoslávský (chorvatský) advokát a politik. Vedoucí představitel Chorvatské rolnické strany, od roku 1928 její předseda. Místopředseda vlády Dragiši Cvetkoviće, na základě jednání mezi těmito dvěma muži byla zřízena Chorvatská bánovina. Maček reprezentoval a symbolizoval zájmy Chorvatů na politické emancipaci v předválečné Jugoslávii. Vstoupil do vlády Dušana Simoviće, při jejím útěku v dubnu 1941 však rezignoval a zůstal v zemi, kde byl vězněn a internován. Na konci války emigroval do Francie a posléze do USA, kde také zemřel.

7 K tomu srov. Jančík, Drahomír: Nèmecko a Malá dohoda: hospodářské pronikáni Německa do Jugoslávie a Rumunska v pruni polovině 30. let. Praha 1990.

8 V roce 1937 uzavřela Jugoslávie smlouvy o přátelství s Bulharskem (24. ledna 1937) a Itálií (25. března), se zeměmi Československu nepříznivě nakloněnými. Srov. např. Deák, Ladislav: Cesta prezidenta Beneša do Juhoslávie v roce 1937. Slovanský přehled 51, 1965, s. 220-227.

9 Karađorđević, Pavle, 1893-1976. Člen jugoslávské královské rodiny, královský regent. Vzdělání získal v Oxfordu, britské prostředí a kultura mu vždy byla velmi blízká. Jakožto syn prince Arsena Karađorđeviće (jenž byl bratrem Petra I., srbského a po válce prvního jugoslávského krále) byl bratrancem krále Aleksandra Karađorđeviće, po jehož zavraždění v roce 1934 se stal regentem za nezletilého Aleksandrova syna Petra. Snažil se o udržení Jugoslávie stranou událostí ve zbytku Evropy ve druhé polovině 30. let a za druhé světové války. Pracoval na uspokojení chorvatských nároků na autonomii, za jeho regentství byla podepsána dohoda Cvetković-Maček. Svržen převratem dne 27. března 1941, posléze internován Brity. Po válce byl v Jugoslávii prohlášen za nepř́tele státu a zůstal do konce života v emigraci. 
byly přičleněny k Německu, respektive Itálii a jejímu vazalskému státu Albánii, Mad’arsku a Bulharsku. Ve zbylých oblastech bylo vyhlášeno Srbsko (oficiálně Území vojenského velitele v Srbsku) a Nezávislý stát Chorvatsko (Nezavisna Država Hrvatska, NDH). Zatímco v Srbsku byla zavedena okupační správa, která byla posléze doplněna o domácí vládu generála Milana Nediće, Nezávislý stát Chorvatsko byl formálně samostatnou zemí, v níž ovšem měly své zóny vlivu, resp. operační pásma vymezeny jak Německo, tak Itálie. V čele tohoto útvaru stál Ante Pavelić, ${ }^{10}$ vůdce teroristické organizace „Ustaša“ usilující o etnicky čisté Velké Chorvatsko.

Vojenský kolaps Jugoslávie, s ohledem k převaze Německa a jeho spojenců prakticky nevyhnutelný, tedy přivedl vládu a krále do exilu. Rodící se exilové státní zřízení zvolilo za své sídlo Londýn, kde Jugoslávci rozmnožili řady exilových vlád a kde také vstoupili do přímého kontaktu se svými československými protějšky. Vzájemné styky, které započaly již v době, kdy se jugoslávská vláda nacházela na útěku, ${ }^{11}$ získaly nové možnosti rozvoje. $\mathrm{V}$ cestě jim však stály přetrvávající problémy v akceschopnosti a celková nejednotnost jugoslávské exilové vlády Tato překážka byla natolik výrazným rysem této vlády, že ji lze prohlásit za její hlavní devizu.

Jugoslávská vláda byla sestavena na území Jugoslávie jako co nejširší uskupení, které mělo tváří v tvář německé hrozbě reprezentovat celou zemi. Proto se v ní nacházeli zástupci všech tří uznávaných konstitutivních národností (kromě Srbů a Chorvatů také Slovinci), ovšem s různými postoji k povaze vnitřního uspořádání i zahraniční politiky státu. V nebezpečí, ve kterém se Jugoslávie od březnového puče do dubnové války nacházela, byla vzájemná spolupráce diktována prostou touhou po mírovém řešení krize. $\mathrm{V}$ britském exilu se však mohly volně projevit vzájemné rozpory. Jedinečné prostředí válečného Londýna, kde se kromě britské vlády nacházelo mnoho jiných exilových státních zřízení a také nejvyšší diplomatická zastoupení dalších dvou protiněmeckých velmocí, skýtalo navíc možnost k vyhledávání spojenců při vnitropolitických bojích mimo jugoslávský exil. Tomuto lákadlu jugoslávští politici všech názorových pozic pravidelně podléhávali.

První exilová vláda v čele s generálem Dušanem Simovićem, jedním z vůdců březnového převratu, se zhostila nelehkého úkolu ustanovit správní aparát, který by Jugoslávii reprezentoval do skončení války a který by připravil koncepci poválečné obnovy země. Byla obsazena zastoupení u spojeneckých i neutrálních států a také navázány či obnoveny styky se spřízněnými exilovými vládami. V případě Československa došlo ke jmenování

10 Pavelić, Ante, 1889-1959. Jugoslávský (chorvatský) právník a politik, chorvatský diktátor. Již za první světové války působil ve Straně práva, z niž posléze usedl do lavic parlamentu v meziválečné Jugoslávii. V této době byl stoupencem republikánství, hájil chorvatskou svébytnost. V průběhu 30. let se jeho názory radikalizovaly a byl nucen v roce 1929 odejít do exilu. Téhož roku založil militantní organizaci Ustaša (česky „Povstalec“), která usilovala o chorvatskou samostatnost násilnými prostředky, podílela se například na zavraždění krále Aleksandra v roce 1934. Bezprostředně po pádu Jugoslávie v dubnu 1941 se s požehnáním Osy chopil v Záhřebu moci a vyhlásil výše zmíněný NDH. Jako jeho vůdce („poglavnik“) inicioval a vedl genocidu Srbů, Židů a Romů na území fašistického NDH. Po válce uprchl do exilu v Jižní Ameriky. Zemřel ve Španělsku.

11 Šlo jednak o skromnou korespondenci E. Beneše a krále Petra, jednak o osobní kontakty jugoslávské vlády s československými orgány v Jeruzalémě. Pospíchal, Jonáš: Odtažitost a vyčkávání. Vztahy exilových vlád Československa a Jugoslávie v letech 1941-1943. Slovanský přehled 102, 2016, s. 466. 
vyslance Većeslava Vildera ${ }^{12}$ v říjnu 1941 a vojenského atašé Vlastimira Rožđalovského v únoru 1942. Úřad československého vyslance byl uznán za formálně fungující již z předválečné doby, a tak vyslanec Jaroslav Lípa, ${ }^{13}$ působící v Bělehradě od roku 1938, v Londýně pouze pokračoval ve své funkci. Ve funkci vojenského atašé jej na počátku roku 1942 doplnil Václav Podhora. ${ }^{14}$ Další akce této vlády na mezinárodním poli zahrnovaly podepsání Atlantické charty 14. srpna 1941 či uzavření dohody o budoucí federaci s exilovou vládou Řecka dne 15. ledna 1942..$^{15}$

Mírné pokroky v zahraniční politice byly více než vyváženy zhoršující se situací vnitropolitickou. Zásadními obtížemi byly rozpory představitelů jednotlivých národností, kteří se byli schopni na počátku svého exilu shodnout pouze na základních obrysech zásad své exilové práce. Tzv. Jeruzalémská deklarace ze 4. května 1941 vyjadřovala pouze odhodlání k jednotnému boji proti okupantům, neuznání obsazení země a také pokračování v politice Sporazumu. ${ }^{16}$ Nicméně právě vidina poválečné obnovy či rozšśření chorvatské autonomie činila velké části srbských ministrů v průběhu války čím dál větší potíže. Zprávy, které přicházely ze země, hovořily až o stovkách tisíc srbských obětí zavražděných v nově vzniklém Nezávislém státě Chorvatsko (NDH), který se kromě dosavadní Chorvatské bánoviny rozkládal na většině území Bosny, Hercegoviny a Sremu. ${ }^{17}$ Tyto zprávy, ač

12 Vilder, Većeslav, 1876-1961. Jugoslávský (chorvatský) právník a politik českého původu. Politicky aktivní byl již za Rakouska-Uherska. Pracoval na ministerstvu vnitra, kandidoval v několika volbách do chorvatského zemského sněmu (Saboru). V meziválečné době zastával protikomunistické postoje. V závěru války se údajně nabídl k dispozici partyzánům. Pro svou blízkost českému prostředí (měl české kořeny) zastával post vyslance u československé exilové vlády, na němž setrval i v prvních měsících po konci války, kdy byl odvolán. Poté odešel do emigrace, kde také zemřel.

13 Lípa, Jaroslav, 1886-1965. Československý (český) diplomat. Vystudoval obchodní akademii v Praze, v první světové válce bojoval v řadách československých legií, které opustil v hodnosti kapitána v záloze. Po válce vstoupil do diplomatických služeb, které vykonával postupně v Rímě, Washingtonu a jako vyslanec v Rize (1935-1938) a posléze v Bělehradě (1938-1945). Po 15. březnu 1939 vyhověl rozkazu z Prahy k předání vyslanectví Němcům, protože neviděl možnost jeho udržení. Toto jednání bylo poválečným vyšetřováním schváleno. V diplomatické a zpravodajské činnosti ovšem pokračoval se svými podřízenými dál, a to až do března 1941. Jako vyslanec působil i u exilové jugoslávské vlády v Londýně, po válce pokračoval ve svém úřadě v Bělehradě. V ř́ínu 1945 byl přeložen do ústředí MZV v Praze.

14 Podobným zpo̊sobem bylo Československo zastoupeno i u ostatních spojeneckých či neutrálních vlád, exilových či zcela suverénních, ale také u doposud fungující Společnosti národů (srov. pasáž o Jaromíru Kopeckém v této práci). K otázkám československé exilové diplomacie viz např. Dejmek, Jindřich: Diplomacie Československa. Díl 1. Nástin dějin ministerstva zahraničních věcí a diplomacie (1918-1992). Praha 2012, s. 93-102.

15 Národní archiv Praha [dále NA], fond Předsednictvo ministerské rady - Londýn [dále f. PMR-L], krabice [dále krab.]. 68, signatura Zprávy Jugoslavie, folio [dále fo.] 1942, zpráva Koordinačního výboru Československo-Polského z 20. ledna 1942.

16 Vlade Kraljevine Jugoslavie u Drugom svetskom ratu (= VKJDSR). Ed. K. Nikolić. Beograd 2008, s. 46, Deklaracija Kraljevske Jugoslovenske vlade, Jerusalim 4. maja 1941.

17 Pravou pohromu pro vládní stabilitu představovalo memorandum Srbské pravoslavné církve, které se v Londýně objevilo na podzim roku 1941. Tento dokument přinášel podrobné údaje o povaze perzekuce Srbů v Chorvatsku, o účasti katolického kléru na nich, pasivitě většiny Chorvatů vưči srbskému strádání a o počtu obětí, který se měl jen do začátku srpna údajně vyšplhat na 180000 . Tento přinejmenším nepřesný text způsobil významnou vládní krizi. Zatímco někteří srbští ministři jako Momčilo Ninčić a Milan Grol požadovali jeho zveřejnění, předseda vlády Dušan Simović prosadil utajení tohoto spisu. V odpověd' na rozhodnutí vlády zprostředkovalo v prosinci 1941 jugoslávské vyslanectví v USA uveřejnění memoranda 
výrazně nadhodnocené, zvýraznily dosavadní neochotu mnoha srbských politiků jakkoliv prohlubovat vliv Chorvatů na řízení exilové vlády i poválečného státu. Zatímco tedy chorvatští ministři pokládali Sporazum za výchozí bod dalších úvah o uspořádání země, jejich srbští kolegové se z velké části vyslovovali pro jeho zásadní revizi. Dřivější potvrzení tohoto dokumentu v Jeruzalémské deklaraci nyní nepovažovali za závazné, a to s ohledem na události v NDH. Autonomní chorvatský celek, at’ už jakékoliv povahy, zkrátka nepovažovali za bezpečný pro srbské obyvatelstvo. ${ }^{18} \mathrm{~S}$ ohledem k tomu, že se srbský i chorvatský etnický prostor prolínal na většině území Bosny a Hercegoviny, byly pansrbské i panchorvatské federalistické koncepce, směřující k ochraně všech př́ílušníků svého národa, vzájemně nekompatibilní. Z tohoto důvodu bylo poválečné uspořádání další úpornou komplikací práce exilové vlády. Krok zpět v podobě přijetí staršího meziválečného centralistického konceptu přitom s ohledem k jeho selhání nebyl přijatelný ani pro jednu stranu. ${ }^{19}$ Pro jednotlivé koncepce autonomních národních správních celků byla jugoslávskými politiky hledána podpora u spojeneckých zemí, Československo nevyjímaje. Po Londýně obíhala nejrůznější memoranda a prohlášení obhajující historickými, lingvistickými a kulturními argumenty plány na Velké Srbsko, Velké Chorvatsko či sjednocení všech Slovinci obývaných území - v rámci Jugoslávie i vně. ${ }^{20}$ Nad problémem povahy budoucího jugoslávského státu se však tyčila i krize jugoslávské myšlenky jako takové. Válečné události vzbuzovaly pochybnosti o možnosti společného soužití jihoslovanských národů, a to od počátku pobytu vlády v exilu. ${ }^{21}$ Vyhlídky na samovolnou fragmentaci Jugoslávie byly nepř́ijemné všem jejím spojencům, tedy i Čechoslovákům. ${ }^{22}$ Situace došla v průběhu následujících let tak daleko, že jednotliví jugoslávští funkcionáři již nebyli obviňování z nacionalismu a šovinismu, naopak byli vždy jmenováni pouze ti, kteří takové smýšlení neprojevovali. ${ }^{23}$ Personální změny, k nimž ve vládách docházelo, na této situaci

v časopise Američki Srbobran, orgánu Srbského národního svazu v USA. Brandes, Detlef: Exil v Londýně: 1939-1943: Velká Británie a jeji spojenci Československo, Polsko a Jugoslávie mezi Mnichovem a Teheránem. Praha 2003, s. 132 a 134, Tomasevich, Jozo: Četnici u drugom svjetskom ratu 1941-1945. Zagreb 1979, s. 240.

18 Radojević, Mira: Izbeglička vlada kraljevine Jugoslavije i jugoslovenska državna idea. In: Drugi svjetski rat 50 godina kasnije. Podgorica 1997, s. 219.

19 Djilas, A.: The contested country, s. 149.

20 V jednom prochorvatském memorandu byl Sporazum Cvetković-Maček popsán takto: „Dohody bylo sice docíleno, ale ne na demokratický a konečný zpuisob. "Jaroslav Lípa toto memorandum označil za úzce chorvatské, s tím, že „bylo vydáno, pokud jsem informován, bez znalosti jihoslovanské vlády a bez jejího uvědoměni je rozšiřováno, což samo ilustruje vzájemný vnitřni poměr Srbů a Charvatri a nebude jistě ani bez vlivu na budoucí vývoj. “NA, f. PMR-L, krab. 69, signatura Zprávy Jugoslavie, fo. 1942, č. j. 521/42/D, Zpráva Jaroslava Lípy o memorandu o chorvatské otázce z 9 . března 1942.

21 Hubert Ripka se dozvěděl o tendencích k vytvoření národních států již na počátku pobytů Jugoslávců v Londýně a informoval o nich vládu. Zápisy ze schůzi československé vlády v Londýně I (1940-1941) (= ZSČV I). Edd. J. Němeček, I. Štovíček, H. Nováčková, J. Kuklík. Praha 2008, s. 597, 32. schůze 19. září 1941.

22 V rozhovoru s Rudolfem Bićanićem, guvernérem exilové Jugoslávské národní banky, zdůraznil v roce 1941 Hubert Ripka, že „dnes záleži na tom, aby všichni spolupracovali, nebot' jen tak mohou dosáhnout obnovy Jugoslávie. Již ted' dělá na Angličany nejhorši dojem, že se mezi sebou stále vádi. Zulášt’ zle pưsobi, když někteři Srbové ř́kají, že nechtěji mít nic společného s Chorvaty, nebo obráceně. "Archiv Ústavu Tomáše Garrigua Masaryka Praha [dále AÚTGM], fond [dále f.] Edvard Beneš II [dále EB II], krab. 113, sign. V86/2, záznam o rozhovoru Huberta Ripky s Rudolfem Bićanićem z 2. prosince 1941.

23 Srov. veškeré zde zmíněné rozhovory, dále zejména Archiv ministerstva zahraničních věcí Praha [dále 
nic nezměnily. Kromě toho byl jugoslávský vládní systém založen na oktrojované ústavě z roku 1931, jež činila ministry odpovědné přímo králi. Petar II., jemuž v září 1941 bylo 18 let, však nebyl s ohledem ke své nezkušenosti schopen svého silného postavení využít k vyřešení personálních a národnostních sporů. Jeho exilové angažmá, které částečně vyplnil studiem v Cambridge, ceremoniálními povinnostmi a neobratnými politickými kroky, lze označit za fiasko. ${ }^{24}$

Poměr exilové vlády Československa k jejímu jugoslávskému souputníkovi byl ve sledovaném období značně problematický. Obtížně řešitelné a v každém případě nevyřešené rozpory v jugoslávské exilové vládě, činily toto těleso obtížným partnerem ke společné politice. Čechoslováci se snažili Jugoslávce podnítit ke zkonsolidování jejich státního aparátu a k utvoření jasné politické linie, která byla pro Edvarda Beneše podmínkou pro jakákoliv konkrétní jednání. Častým tématem Československých odsudků byla politická neschopnost, tedy špatná „řemeslná“ politická práce jugoslávských představitelů. ${ }^{25}$ Pomoc, kterou k tomu Čechoslováci poskytovali, se omezovala na obecné rady a poskytnutí jistého technického zázemí, kterým československé exilové státní zřízení disponovalo. Do vnitropolitických sporů Jugoslávců nicméně Čechoslováci přímo nezasahovali, možná s ohledem na akce jejich „mentora,“ Velké Británie.

Permanentní jugoslávská krize, která v průběhu let pouze měnila svoji intenzitu, byla doprovázena válkou s okupanty a kolaboranty ve vlasti, která přerostla ve válku občanskou. Její průběh dále prohluboval názorové rozdíly mezi různými jugoslávskými exilovými politiky a vojáky. Byl to také právě její výsledek, a nikoliv závěry učiněné v nestabilních londýnských exilových jugoslávských vládách, který určil poválečnou podobu země jako komunisty vedené republiky. Pokračování jugoslávského boje s Osou reprezentovaly v průběhu druhé světové války zejména dvě domácí hnutí odporu - tradicionalističtí, roajalističtí četnici a komunističtí partyzáni. ${ }^{26}$ Počátek bojů obou dvou lze datovat do polovi-

AMZV], fond Londýnský archiv - důvěrný [dále f. LA-D], krab. 78, č. j. 1572/dův/42, rozhovor Josefa Korbela s Većeslavem Vilderem z 10. dubna 1942: „Členové jugoslávské vlády jsou v Jugoslávii naprosto zdiskreditováni (...) za jediného pokrokového človèka se pokládá Srdan Budisavljević (...) jediný, kdo ještě věři a pracuje o obnově Jugoslávie, jest [Juraj - pozn. J. P.] Krnjević. “"

24 Jeden ze srbských ministrů, Milan Grol, označil krále za „kluka na trůně. “ Nepovažoval jej za politicky vzdělaného a přisuzoval mu též neschopnost formulovat jakýkoliv politický názor. „Mladi muži jeho věku už piši knihy. On je určitě nečte. "Radojević, Mira: Milan Grol. Beograd 2014, s. 265.

25 Takto byli kritizováni postupně všichni předsedové vlád. Za výrazně neobratného byl označován Božidar Purić, na jehož adresu (v souvislosti s memorandem zaslaným Sovětům o Mihailovićově nevině, kterou měli dokázat svým svědectvím sovětští váleční zajatci přeběhnuvší k četnikům) Hubert Ripka uvedl natolik peprný komentář, že jej zapisovatel bohužel odmítl zařadit do zápisu ze schůze vlády a nahradil jej tečkami. AÚTGM, f. EB II, krab. 183, sign. V176D, zápis ze 122. schưze vlády, 11. února 1944. Jako politicky naivní či neschopní byli v průběhu kontaktů s Čechoslováky dále označeni např.: Momčilo Ninčić, Milan Grol, Srđan Budisavljević, Većeslav Vilder, Sava Kosanović, Jovan Banjanin a král Petar II. se svou matkou.

26 Odlišnosti mezi těmito dvěma odbojovými proudy začínaly již na úrovni bojové strategie. Četnici zakládali svůj postup na vyhýbání se větším útokům proti ozbrojené moci okupantů, vyjma obrany civilního obyvatelstva, z něhož se mužstvo rekrutovalo. Četnici tak navazovali na staletí staré techniky mobilní guerillové války ve stylu „udeř a uteč," které měly v balkánském prostoru dlouhou tradici z dob tureckého panství. Partyzáni počítali s aktivním bojem s okupanty, s vytvářením osvobozených území a $\mathrm{k}$ němu př́ílušného správního aparátu. Represe okupantů, které tento postup nevyhnutelně vyvolával, považovali partyzáni za nevyhnutelné a př́slušné ztráty mezi civilním obyvatelstvem za ospravedlnitelné. Tejchman, Miroslav 
ny roku 1941. K rozvoji jejich aktivit organizací musela exilová vláda zaujmout stanovisko. Vláda se postavila za četniky v čele s Dragoljubem Mihailovićem, důstojníkem pravidelné armády. Četnici byli vládou uznáni za oficiální vojsko země a D. Mihailović byl v lednu 1942 jmenován ministrem vojska a námořnictva ve vládě Slobodana Jovanoviće. Poté, co na podzim 1941 selhalo několik pokusů o rovnoprávnou spolupráci či alespoň o sjednání vzájemného neútočení s partyzány, vzplanul jejich otevřený konflikt, který se doplňoval s boji s italskými, bulharskými a německými jednotkami. Pomoci těchto okupantů měli podle partyzánů četnici aktivně využívat, a to na základě rozkazů samotného D. Mihailoviće. Od zániku křehké spolupráce s četniky na podzim 1941 operovali partyzáni pod vedením Josipa Broze Tita v rozsáhlých oblastech Bosny a Chorvatska. V průběhu let 1941 a 1942 dosáhli řady úspěchů a jimi spravované území se několikanásobně rozrostlo. Politická linie partyzánského hnutí byla založena na spolupráci různých odbojářských skupin pod vedením komunistické strany. Jedinou podmínkou pro začlenění do jejich řad byla schopnost modu vivendi s komunisty, kteří tvořili vedoucí kádr partyzánských jednotek, a přirozeně ochota bojovat s okupanty a kolaborantskými silami. Mezi ně partyzáni počítali také četniky, s nimiž sváděli neustálé boje. Příslušníci partyzánských jednotek navíc nebyli, na rozdíl od četniků, u nichž dominoval srbský prvek, charakterizováni určitou národností či konfesní př́íslušností.

Stanovisko exilové vlády k partyzánům bylo negativní kvůli dlouhodobě antikomunistické povaze jak meziválečného jugoslávského establishmentu, tak exilové vlády samotné. Oficiální podpora vlády četnikům nebyla v jugoslávském exilu jednomyslná, nebot zejména mnozí chorvatští politici vnímali tyto jednotky jako hrozbu pro Chorvaty a jejich státoprávní svébytnost. Takto smýšlející chorvatští (ale též někteří srbští a slovinští) představitelé svůj odpor ke komunistickým partyzánům v průběhu války revidovali. ${ }^{27}$ Podepsaly se na tom jistě i vojenské úspěchy Titových jednotek. ${ }^{28}$

Svou podporu k partyzánům přesunuly také vedoucí země protihitlerovské koalice. Spojenecká podpora partyzánům, ujednaná na Teheránské konferenci ve dnech 29. listopadu - 1. prosince 1943, pro ně znamenala výrazný politický úspěch, bez ohledu na to, že tato podpora měla být striktně vojenská. Paralelně s jednáním vedoucích zemí protihitlerovské koalice se v bosenském Jajci konalo od 29. listopadu 1943 druhé zasedání Antifašistické rady národního osvobození Jugoslávie (Antifašističko veće narodnog oslobođenja Jugoslavije, AVNOJ). Vedoucí úloha komunistů měla být vněǰškově zmírněna volbou nového předsednictva AVNOJ, z jeho 63 členů bylo pouze 21 komunistů. AVNOJ se prohlásil za nejvyšší vládní orgán Jugoslávie. Exilové vládě byly odňaty pravomoci zákonné vlády a králi Petrovi byl zakázán návrat do země. Otázka státní formy měla být nicméně vyřešena po válce, rozhodnutím lidu. Josip Broz Tito, strůjce králova odstavení, obdržel vojenskou hodnost maršála. Mezi další výsledky zasedání patřilo vyhlášení federativního principu obnovené země, která měla garantovat rovnoprávnost Srbů, Chorvatů, Slovinců,

Balkán ve válce a v revoluci 1939-1945. Praha 2008, s. 399-400.

27 Djilas, A.: The contested country, s. 147-148.

28 Do listopadu 1943 kontroloval AVNOJ již polovinu celé rozlohy předválečné Jugoslávie a v jejích národněosvobozeneckých jednotkách bojovalo přes 300 tisíc vojáků. Tejchman, M.: Balkán, s. 455. 
ale také nově Makedonců a Černohorců jakožto svébytných národnostních skupin, respektive př́íslušných územních celků.

Rostoucí převaha partyzánského hnutí nad exilovou vládou i jí přinejmenším formálně podléhajícím četnickým jednotkám D. Mihailoviće, nebyla samozřejmě přehlédnuta československou vládou.

\section{Od krále. Odklon Čechoslováků od exilové vlády 1943-1945}

Míra chaosu v exilové vládě Jugoslávie překonala v létě 1943 hranici, kdy ji bylo možno řešit politickým konsenzem. Došlo ke jmenování úřednické vlády v čele s dlouholetým srbským diplomatem Božidarem Purićem. ${ }^{29}$ Vztahy Jugoslávců s Čechoslováky se tímto dále zhoršily, nebot Božidar Purić považoval československou exilovou vládu za příliš prosovětskou. ${ }^{30}$ Zatímco jugoslávské exilové státní zřízení považovali Čechoslováci za zcela odtržené od domovské země a bez vlivu na tamější události, Purićova nestranická vláda byla hodnocena jako nereprezentativní i podle měřítek exilového prostředí. Etablovaní straničtí politici se přirozeně svých aktivit nevzdali a nadále se stýkali i s československými činiteli. ${ }^{31} \mathrm{Z}$ těchto důvodů hodnotili Čechoslováci vládu B. Puriće jako mimořádně nevhodnou. Tento negativní postoj byl dále umocněn některými netaktními akcemi či opomenutími, kterých se jugoslávská královská vláda, sídlící tou dobou v Káhiře (za účelem bližšího kontaktu s jugoslávskými vojáky v Egyptě i pro blízkost k jugoslávskému teritoriu), dopustila. ${ }^{32}$

29 Purić, Božidar, 1891-1977. Jugoslávský (srbský) politik a diplomat. Účastnil se balkánských válek i první světové války. Jako diplomat působil ve Washingtonu, Vladivostoku, San Francisku a Pařízi. Publikoval v odborných časopisech o mezinárodní politice, vydal také sbírku básní. Působil jako předseda předposlední exilové vlády. Po válce zůstal v emigraci, kde také zemřel.

30 Petranović, Branko: Odnosi jugoslovenske i čehoslovačke vlade u emigraciji 1941-1945. Vojnoistorijski glasnik 41, 1990, s. 54.

31 Dne 15. záŕí 1943 obědval Ladislav Feierabend s Većeslavem Vilderem, Lazarevićem, Milanem Grolem a jedním dalším Jugoslávcem. Bez dalších detailů mu jeden z nich smutně shrnul dosavadní působení jugoslávské exilové vlády tak, že se o ni zpočátku staral britský Foreign Office, poté Intelligence Service a nyní už pouze Scotland Yard. Válečné deniky Jana Opočenského. Edd. J. Čechurová - J. Kuklík - J. Čechura - J. Němeček - J. Opočenský. Praha 2001, s. 309, zápis z 15. zář́ 1943.

32 Jugoslávská vláda odmítla přijmout k nástupní audienci majora V. Podhoru, když se, jakožto vojenský atašé, pokusil dne 24. listopadu u královské vlády ohlásit. AÚTGM, f. EB II, krab. 454, č. j. 13/dův/43, opis zprávy majora Podhory o zdrženlivosti Jugoslávců z 13. prosince 1943. Na počátku prosince se pak Edvard Beneš, v rámci své cesty do Moskvy za účelem podepsání spojenecké smlouvy se SSSR, zastavil v Káhiře, kde se sešel s předsedou jugoslávské vlády. Ten československému prezidentovi přednesl žádost o zprostředkování jugoslávsko-sovětské smlouvy na podobných základech, na jakých se Sověty jednali Čechoslováci. Tuto žádost Beneš přijal, byl si však dobře vědom toho, že nemá naději na úspěch. Tamtéž, krab. 183, sign. V176D, zápis ze 118. mimořádné schůze vlády, 11. ledna 1944, referát Edvarda Beneše o Jugoslávii. Na zpáteční cestě z Moskvy se E. Beneš opět zdržel v Káhiře. Československý prezident projevil v posledních dnech roku 1943 zájem o setkání s jugoslávským králem, ten se měl ovšem nacházet mimo své sídlo. K setkání $\mathrm{s}$ králem nedošlo, a to, jak českoslovenští úředníci vypátrali, díky intrice $\mathrm{B}$. Puriće, který zatajil králův návrat z cesty tak, aby se s ním prezident Beneš před návratem do Londýna nestačil setkat. AMZV, f. LA-D, krab. 80, č. j. 2344/dův/44, zpráva o návštěvě prezidenta u jugoslávského krále, 14. března 1944. 
Rozvoj aktivit partyzánského hnutí, jehož nejvýraznějším projevem byl sjezd v Jajci, znamenal přímou výzvu exilové vládě. Konfliktní potenciál existence dvou vlád, jedné faktické a druhé oficiálně uznané, nebylo možno popřít. V odpověd' na toto riziko rozvinuli své operace Britové, kteří se snažili o dosažení modu vivendi obou vlád a v prủběhu roku 1944 pracovali k jejich sjednocení s co nejlepšími pozicemi nekomunistů. Čechoslováci, kteří ostatně nedisponovali příslušnými prostředky, byli odtažitější a skromnější. Edvard Beneš definoval další československou politiku k Jugoslávii takto: „Učiníme vše, abychom zabránili jakýmkoliv pokusům o rozděleni Jugoslávie na Srbsko, Chorvatsko aj. (...) Na to ostatni musime čekat, jak si to dále oni udělaji. “33 Čechoslováci měli ke sporům mezi partyzány a exilovou vládou přistupovat neutrálně a pouze se zasazovat o jednotu země. $\mathrm{V}$ praxi však tato formulace vedla k podpoře partyzánů, kteří se svou rostoucí silou představovali onen prvek jednoty země, kterou slábnoucí exilová vláda naopak ohrožovala. Na 115. schůzi dne 10. prosince 1943 se Hubert Ripka ${ }^{34}$ vyjádřil ke komunisty vedenému hnutí příznivě, opět spíše díky jejich porovnání s exilovou vládou: „Nelze popřit, že naše sympatie jsou na straně partyzánů, ne vlády, jako je Purićova. "35 Zdrženlivost vưči oficiální jugoslávské vládě, ale prozatím i vưči partyzánům, je dobře patrná z události, k níž došlo v polovině ledna 1944. Tehdy bylo československému MZV předáno z MNO několik starých telegramů z Jugoslávie, údajně přímo od generála Mihailoviće. Jeden z nich, datovaný do 23. srpna 1943, uváděl, že se v Sandžaku nacházel prapor německých ozbrojených sil, složený ovšem z Čechů a Poláků. Telegram radil, aby jim byla příslušnými exilovými vládami zaslána výzva k přeběhnutí. Vojenský atašé u jugoslávské vlády major V. Podhora toto doporučení schvaloval, ovšem s výhradou, aby nebyli tamější Češi vyzváni k přeběhnutí k jugoslávskému vojsku, protože by tím byli vybídnuti ke vstupu do jednotek D. Mihailoviće. Varoval však také před pokynem k přechodu k partyzánům. Major tedy radil, aby výzva byla stylizována „jako výzva ke vstupu do nejbližši jednotky bojujicí proti Němcům, se současným varováním neúčastniti se vnitřního boje v Jihoslavii. “ Dne 18. ledna 1944 se k věci vyjádřil Hubert Ripka, když celý spis předal vyslanci u jugoslávské vlády. J. Lípa měl československé vojáky pohnout k tomu, aby se připojovali k bojujícím jugoslávským vojákům, a přitom naznačit spiše naše sympatie pro vojsko Titovo. ${ }^{36}$

Zaslání výzvy bylo zahraničním úřadem schváleno a postoupeno ministerstvu národní obrany. Tento dokument je velmi zajímavým dokladem československého postoje

33 AÚTGM, f. EB II, krab. 183, sign. V176D, zápis ze 118. mimořádné schůze vlády, 11. ledna 1944, referát Edvarda Beneše o Jugoslávii.

34 Ripka, Hubert, 1895-1958. Československý (český) novinář, historik a politik. Ve dvacátých letech působil jako redaktor Lidových novin, vydával publikace o SSSR, Francii a Jugoslávii. Tu také osobně navštívil v roce 1937 jako vyslanec prezidenta Beneše, aby prozkoumal politické podmínky v zemi a její připravenost k podpoře Československa proti Německu. Za druhé světové války byl jedním z vedoucích činitelů exilového státního zřízení. V letech 1940-1941 státním tajemníkem na exilovém MZV, v letech 1941-1945 státním ministrem tamtéž (šéfem resortu zůstával Jan Masaryk). Po válce ministrem zahraničního obchodu. V únorové krizi v roce 1948 odstoupil a záhy poté odešel do emigrace. Působil v Radě svobodného Československa. Zemřel v Londýně, kde žil od roku 1955.

35 Zápisy ze schưzi československé vlády v Londýně III.2 (červen-prosinec 1943) (= ZSČV III.2). Edd. Němeček, J., Štovíček, I., Nováčková, H., Kuklík, J., Bílek, J.. Praha 2013, s. 473, 115. schůze vlády dne 10. prosince 1943.

AMZV, f. LA-D, krab. 80, č. j. 478/dův/44, Telegramy z Jihoslavie, 20. ledna 1944. 
nejen k četnickému vojsku, ale k jugoslávské exilové vládě jako celku. Vojenský atašé se ve zprávě pro svou vládu přimlouvá za to, aby oficiální armáda spojenecké země nebyla považována za natolik důvěryhodnou, aby byli Čechoslováci vyzváni k přidružení se k ní. Ministr Hubert Ripka zmocňuje vyslance u jugoslávské vlády Jaroslava Lípu, aby naznačil Čechoslovákům prospěšnost vstupu do vojska, které pouze o několik dnů dříve jugoslávská vláda označila za teroristy. ${ }^{37}$ Přirozeně proto nepřekvapí, že prezident Beneš odmítl odpovědět na telegramy zaslané mu ze dvou D. Mihailovićem organizovaných kongresů na počátku roku 1944, které měly zapůsobit jako odpověd' na kongres AVNOJ. ${ }^{38}$

Přímá spolupráce s jugoslávskou exilovou vládou byla již v první polovině roku 1944 výrazně řidší než v předchozích letech. Jediným dokladem o ní, či o pokusu o ni z této doby je snaha Čechoslováků z dubna 1944 navázat na svůj dřívější dotaz u jugoslávského ministerstva financí. Zde se na jaře 1942 snažila československá vláda získat inspiraci k zorganizování vlastní registrační služby válečných škod. Bylo zjištěno, že se po dva roky, navzdory př́ležitostným urgencím, celé věci u Jugoslávců nikdo nevěnoval. ${ }^{39}$ Obraz jugoslávské exilové vlády u jejich československých kolegů se dále zhoršoval. V obsáhlé analýze z března 1944 popsal V. Podhora situaci v jugoslávském exilu, ale i v okupované zemi, a připojil též důkladnější informace o složení a povaze partyzánů. ${ }^{40}$ Královskou vládu pod Purićovým předsednictvím vylíčil ve značně negativním světle. Jednotliví ministři měli být proti partyzánům do té míry, že byli vděčni za německé úspěchy v bojích s nimi. Celá vláda pak byla zmítána kompetenčními spory a boji o moc. Československý důstojník ve své zprávě nešetřil ani mladého monarchu. ${ }^{41} \mathrm{~V}$ pramenech, které vypovídají o následujících měsících roku 1944, výrazně ubylo zmínek o běžných kontaktech mezi jugoslávskými a československými politiky působícími v Londýně. ${ }^{42}$

Větší intenzity nabývaly styky Čechoslováků a Jugoslávců díky práci stálého delegáta u Společnosti národů Jaromíra Kopeckého, ${ }^{43}$ který od roku 1937 působil jako českoslo-

37 Tamtéž, krab. 79, č. j. 4330/dův/43, zpráva o prohlášení jihoslovanské exilové vlády ke kongresu v Jajci z 6. prosince 1943 a AÚTGM, f. EB II, krab. 453, sign. 40/99/XVIII/Jugoslávie/1, č. j. 3844/dův/43, zpráva o reakci na prohlášení jihoslovanské exilové vlády ke kongresu v Jajci z 10. prosince 1943.

38 AMZV, f. LA-D, krab. 80, č. j. 1918/dův/44, Kongres Sjednocené demokratické mládeže jihoslovanské poselství p. prezidentovi dru E. Benešovi, 29. února 1944.

39 Tamtéž, krab. 81, č. j. 932/dův/44, zpráva o stavu registrace válečných škod u jugoslávské vlády z 11. srpna 1944.

40 Tamtéž, č. j. 3104/dův/44, zpráva o poměrech v Jugoslávii z 31. března 1944.

41 „[Král] byl častěji opit $i$ ve veřejných lokálech (...) Mirkovič mi vyprávél o fotografii, kterou mu ukazoval anglický letec, kde král ležel na divaně úplně zpit v náruči jakési dámy. “Jugoslávské exilové státní zřízení bylo podle Podhory obrazem marnosti a chaosu: „Někdy po celé dny se [funkcionáři a důstojníci] nedostavi do kanceláre. Nikdo nevi, kde jsou. (...) Téměř všichni důstojníci maji soukromé byty, několika pokojové s vlastními kuchaři a sluhy. (...) Doma zpustošená země, která po válce bude vypleněna a vykradena s miliony oběti a zde lidé utráceji nesmírné penize. (...) Je to rozklad, který v mnohém pripomíná život carského Ruska. - podtrženo později tužkou, nejspíš rukou Huberta Ripky. Tamtéž.

42 Styky byly omezeny i na úrovni vyslanců. Zatímco drtivá většina zpráv J. Lípy o jugoslávské exilové vládě z roku 1943 byla tvořena právě popisy kontaktů s exilovými Jugoslávci, v roce 1944 se jich plná polovina týkala kontakty s partyzány v Londýně, zprávami o jejich bojích v Jugoslávii a jejich styky s exilovou vládou. Srov. AÚTGM, f. EB II, krab 453.

43 Kopecký, Jaromír, 1899-1977. Československý (český) novinář, právník a diplomat. Od 1. listopadu 1937 sloužil na vyslanectví v Bernu a u Společnosti národů v Ženevě. Po 15. březnu vstoupil do služeb rodící- 
venský diplomat ve Švýcarsku. V této zemi se střetávala zastoupení všech válčících zemí, stejně jako političtí emigranti a tajné služby ze všech zemí kontinentu. Jaromír Kopecký, jehož pozice u Společnosti národů přečkala turbulentní období rušení československých vyslanectví po 15. březnu 1939, ${ }^{44}$ zprostředkoval spojení mezi exilovou vládou Jugoslávie a politickými skupinami z Chorvatska, Slovinska i okrajově i Srbska, které měly v Ženevě své vyslance. Tito Jihoslované upřednostňovali Jaromíra Kopeckého před oficiálním jugoslávským vyslancem v Bernu Momčilo Jurišićem, jenž měl být údajně srbským nacionalistou, a proto nepřátelským $\mathrm{k}$ některým jugoslávským odbojovým skupinám. ${ }^{45}$ Tato spolupráce ve formě zprostředkovatelských služeb kulminovala právě v roce 1944, kdy mezi Jugoslávií, Ženevou a Londýnem putovaly desítky zpráv. Jejich povaha byla často osobní a jejich politický dopad nevýznamný. Samy vypovídaly o postojích jednotlivých domácích i exilových jugoslávských politiků k lokálním událostem v zemi a ke vztahům mezi funkcionáři některých politických stran. Kvůli omezenému vlivu adresátů i pisatelů těchto zpráv nelze přeceňovat ani dopad oněch informací, pokynů a proseb, které se dotýkaly důležitých témat poválečného uspořádání celé země, srbsko-chorvatského soužití či geopolitické pozici Jugoslávie po válce. ${ }^{46}$ Tyto kontakty byly však odůvodněnou výjimkou z jinak jednoznačně sestupné tendence kontaktů mezi exilovými Čechoslováky a Jugoslávci.

\section{K maršálovi. Zesílení kontaktů s partyzány 1944-1945}

V době upadajících styků s exilovou vládou stoupal naopak význam jednání s partyzány. Od jara 1944 probíhaly v Londýně rozhovory mezi Vladimirem Velebitem ${ }^{47}$ Hubertem

ho se československého zahraničního odboje, přihlásil se k věrnosti Edvardu Benešovi. Podařilo se mu uchovat kontinuitu Úřadu Stálého delegáta při Společnosti národů, v roce 1942 dosáhl jejího oficiálního uznání. Udržoval styky s různými skupinami emigrantů a odbojářů ve Švýcarsku. Jugoslávské emigrantské skupiny podporoval tak, že přes své nadřízené ve Velké Británii zprostředkovával jejich korespondenci s jejich londýnským ústředím. Od března 1945 krátce působil jako vyslanec u švýcarské vlády. Po únorovém převratu v roce 1948 byl propuštěn z diplomatických služeb, při pokusu o emigraci byl dne 8. srpna 1949 zatčen a odsouzen za protistátní činnost. Zemřel dne 6. května 1977.

44 Na post delegáta při Společnosti národů (SN) se nevztahovala nařízení k převzetí vyslanectví. Po přečkání krizového období, kdy hrozila ze strany SN absorpce př́islušných zastoupení okupovaných území Německem a Itálií, byl v listopadu roku 1942 Kopeckého úřad oficiálně obnoven a uznán. Ženeva. Politické paměti 1939-1945. Ed. J. Kopecký- J. Němeček. Praha 1999, s. 12-13 a Němeček, Jan: Soumrak a úsvit československé diplomacie. 15. březen 1939 a československé zastupitelské úřady. Praha 2008, s. 210-214.

45 Kopecký, Jaromír: Paměti diplomata. Praha 2004, s. 364.

46 Celkově předal J. Kopecký za dobu svého působení 68 dochovaných zpráv. Pro další údaje o této zprostředkovatelské činnosti J. Kopeckého viz Pospíchal, Jonáš: Československý delegát u Společnosti národů jako pojitko mezi jugoslávským exilem a vlasti 1941-1945. Edice pramenů a komentovaná analýza. Nepublikovaná bakalářská diplomová práce. Historický ústav FF MU. Brno 2016.

47 Velebit Vladimir, 1907-2004. Jugoslávský (srbský, resp. srbsko-slovinský) voják, právník a politik. Působil jako právník v Niši, byl perzekvován pro své levicové názory a po setkání s Titem v roce 1939 vstoupil do ilegální Komunistické strany Jugoslávie. V době druhé světové války zůstal v zemi a účastnil se odboje. Jakožto členu či veliteli různých misí v Jugoslávii i v zahraničí mu byly svěřeny důležité úkoly v navazování styků se spojeneckými, ale také nepřátelskými úřady. Po válce pokračoval ve své diplomatické kariéře. Zemřel v Záhřebu. 
Ripkou a ministrem národní obrany, generálem Sergějem Ingrem. ${ }^{48}$ V. Velebit Čechoslováky informoval o rozvoji partyzánského hnutí a o dalších plánech na emancipaci národně-osvobozeneckého vojska mezi spojenci. ${ }^{49} \mathrm{~K}$ jednání s partyzány docházelo intenzivně i v samotné Jugoslávii, kde začala 9. července 1944 působit československá vojenská mise. ${ }^{50}$ Spíše než ze spontánního nadšení k partyzánům přistupovali Čechoslováci k rodící se nové Jugoslávii jako k faktickému stavu věcí, díky němuž bylo zabráněno nejhoršímu, tedy úplnému propadu jugoslávské státní myšlenky.

Dne 1. června 1944 byl ministerských předsedou jmenován předválečný bán Chorvatské bánoviny Ivan Šubašić. ${ }^{51}$ Československý poměr k vládě, kterou následně sestavil, byl rozhodně příznivější než k jejím předchůdkyním. ${ }^{52}$ Námitky proti údajně příliš „pravicové“ povaze tohoto tělesa vznesené z řad partyzánů pobývajících v Moskvě, které do Londýna předal tamější československý vyslanec Zdeněk Fierlinger, vyslanec Jaroslav Lípa odmítnul a I. Šubašiće i jeho vládu hájil. ${ }^{53}$ Polooficiální časopis exilové vlády Čechoslovák přinesl v této době obsáhlý článek, jehož autory byli Čechoslováky př́iznivěji přijímaní politici v čele s Milanem Grolem ${ }^{54}$ a Većeslavem Vilderem. Jeho obsahem byl manifest těchto politiků různých národností, kteří se vyslovovali pro jednotu všech protiněmeckých sil, pro poválečné demokratické a federalistické uspořádání země a rovnoprávnost

48 Ingr, Sergěj, 1894-1956. Československý (český) důstojník. Za první světové války vstoupil do československých legií, přijal pravoslaví a jméno Sergěj (původním jménem byl Jan). V armádě zůstal jako profesionál. Bojoval ve válce o Slovensko (1918-1919), postupně stoupal ve vojenské hierarchii. Ve druhé světové válce se podílel na organizaci československých dobrovolníků, následně vstoupil do exilové vlády jako ministr národní obrany. Na konci války byl pro své nepřátelství ke komunistům na jejich nátlak z vlády odstaven. Působil jako zvláštní vyslanec v Haagu. Po únorovém převratu v roce 1948 zůstal v emigraci, kde se podílel na založení Rady svobodného Československa. Zemřel v Paříži.

49 AMZV, f. LA-D, krab. 80, č. j. 3643/dův/44, zpráva o rozmluvě s generálem Velebitem a majorem Vogelnikem, 12. května 1944.

50 Zudová-Lešková, Zlatica: Zapomenutá elita. Českoslovenští vojenští diplomaté v letech 1938-1945. Praha 2011, s. 208.

51 Šubašić, Ivan, 1892-1955. Jugoslávský (chorvatský) právník a politik. Studoval teologii, bojoval v první světové válce na straně Rakousko-Uherska, po zajetí vstoupil do spojeneckého vojska a účastnil se ofenzivy na frontě u Soluně v závěru války, která vedla k osvobození Srbska a obsazení Bosny a Chorvatska. Po válce členem Chorvatské rolnické strany. Po napadení Jugoslávie v roce 1941 odešel do exilu, kde se v červnu 1944 stal předsedou vlády jako kompromisní kandidát přijatelný pro exilové politiky i partyzány. S těmi spolupracoval i po osvobození země. Zastával post ministra zahraničních věcí ve vládě Josipa Tita. Rezignoval na podzim 1945 pro nesouhlas s narušováním svobod. Zůstal v Jugoslávii, kde také v ústraní dožil.

52 Podle Huberta Ripky se o ni československá vláda sama zasadila, když tlačila na Brity a Sověty, aby se rozhodli pro podporu vlády politické a nikoli úřednické. AÚTGM, f. EB II, krab. 183, sign. V176D, zápis ze 140. schůze vlády 26. května 1944.

53 AMZV, f. LA-D, krab. 80, č. j. 5445/dův/44, prodomo zpráva o Fierlingerově depeši z Moskvy s připojeným Lípovým vyjádřením z 18. července 1944.

54 Grol, Milan, 1876-1952. Jugoslávský (srbský) literát a politik. Jakožto jeden ze zakladatelů Demokratické strany stál v opozici vůči radikálním velkosrbským politikům. Věnoval se teatrologii a literární kritice, působil v Národním divadle. Účastnil se několika exilových vlád a přijal též post v poválečné vládě Josipa Tita jako její místopředseda. Odešel na počátku srpna 1945 kvůli narušování občanských svobod novým režimem. Dožil v ústraní v Bělehradě. 
tří konstitutivních národů. ${ }^{55}$ Toto epizodní, vnějškové zlepšení postoje Čechoslováků k jugoslávské vládě neznamenalo žádnou změnu v hodnocení jihoslovanského exilu jako celku. V téže době například Hubert Ripka odmítl předat Mihu Krekovi ${ }^{56}$ jeden ze vzkazů z okupované země, který pro něj přeposlal ze Ženevy J. Kopecký. Jednalo se o zprávu ze Slovinska, kde mělo dojít k aktům spolupráce partyzánů s Němci, což byla zpráva, která mohla smiřování exilové vlády s partyzány zkomplikovat. ${ }^{57}$ Předávání zpráv mezi Jugoslávií a Londýnem nicméně pokračovalo. Ochotněji předali Čechoslováci vzkazy o zatýkání ve Švýcarsku, jehož objektem byli tamější sympatizanti partyzánů, ${ }^{58}$ spolu s žádostí o zákrok skrze Londýn. Zpráva byla okamžitě doručena na př́íslušná místa. ${ }^{59}$

Na podzim 1944 osvobodila národně-osvobozenecká vojska již větší část země, obsáhla většinu Srbska a 20. ř́ína 1944 vstoupila spolu s Rudou armádou do Bělehradu. Osvobození větších měst v čele s jugoslávskou metropolí doprovázela celá řada problémů; kromě těch vzešlých z nutnosti správy dlouhodobě okupovaných území se jednalo i o akty politického násilí proti kolaborantům, ale i proti potenciálním odpůrcům partyzánů. Zprávy o těchto represích nyní putovaly k československé vládě díky jejím vlastním zpravodajům. ${ }^{60}$ Ani tyto, ani jiné zprávy získávané od spojenců již přirozeně nic nezvrátily na československé podpoře partyzánům Josipa Tita, diktované zejména nutností reálné politiky. ${ }^{61}$ Čím dál větší část styků československé exilové vlády byla od podzimu vedena př́mo s novými jugoslávskými orgány v Bělehradě. Již v červenci 1944 pak byl od exilové vlády odvolán major Václav Podhora. ${ }^{62}$ V září 1944 navrhl Vladimír Velebit Čechoslovákům jednání o otázkách poválečné hospodářské spolupráce ${ }^{63}$ a v listopadu začal v československých táborech v Británii výcvik jednotek sestavených ze zajatců jihoslovanských národností bojujících na straně Wehrmachtu. Tito vojáci byli od ledna 1945 odesíláni do Itálie a následně zařazeni do partyzánských jednotek. ${ }^{64}$ Udržování styků s Titem

55 Základni otázky jihoslovanské politiky. Čechoslovák, roč. VI, č. 24, 16. června 1944, s. 6.

56 Krek, Miha, 1897-1969. Jugoslávský (slovinský) advokát a politik. Aktivní byl ve straně slovinských křestanských demokratů. V meziválečné době pracoval ve státních službách. V exilu zastával post ministra stavebnictví a místopředsedy vlády. Byl jedním z odpůrců dohody Tito-Šubašić. Po válce zůstal v emigraci.

57 AMZV, f. LA-D, krab. 80, č. j. 6237/dův/44, Koncept odpovědi na šifrogram čís. 448 ze dne 7. srpna t. r. dra Kopeckého, Ženeva, odeslán 16. srpna 1944.

58 Důvodem těchto akcí mělo být jejich porušování švýcarské neutrality protitovskou propagandou a podezření, že chtěli v zemi založit vojenskou organizaci. AÚTGM, f. EB II, krab. 113, sign. V86/4, značka Bgl 0722775-44, zpráva ze dne 27. července 1944.

59 AMZV, f. LA-D, krab. 80, č. j. 5702/dův/44, Ženeva, vzkaz pro Mihajla Petroviće, 25. července 1944.

60 AÚTGM, f. EB II, krab. 113, sign. V86/4, značka JIT 100602-44 a NA, Ministerstvo vnitra - Londýn, krab. 245, sign. 2-59-30.

61 O povaze nového jugoslávského státního zřízení se diskutovalo i v československé vládě: „Min. Ripka: (...) Stoupenci Titovi si představuji, že nebudou politické strany, ale národni fronta, která se dohodne na kandidátní listině.....Min. Lichner: To je diktatura. Min. Ripka: Ne, nová forma demokracie. [podtrženo později tužkou]. “ AÚTGM, f. EB II, krab. 184, sign. V176D, zápis ze 176. schůze vlády, 16. prosince 1944.

62 Zudová-Lešková, Z.: Zapomenutá elita, s. 204.

63 AÚTGM, f. EB II, krab. 454, č. j. 3328, zpráva o rozmluvě Josefa Korbela s generálem Velebitem, 26. září 1944.

64 Plachý, Jiří: Československý podíl na spojenecké pomoci při výstavbě jugoslávských jednotek v letech 1944-1945. Příspěvek k československo-jugoslávským vztahům. Slovanský přehled 96, 2010, s. 165-166. 
bylo naléhavější než v případě královské vlády: v Jugoslávii se nacházel československý majetek, v partyzánských jednotkách bojovali Čechoslováci a bylo též nutné odpovědět na pokusy o kontakt, které již dříve činili Češi a Slováci v Jugoslávii trvale usazení. Odrazem těchto skutečností jsou proměny dochované pramenné základny. Od podzimu 1944 hovoří převážná většina dokumentů o akcích spojených s těmito tématy. ${ }^{65}$

Výjimkou z tohoto trendu byl závěr splynutí obou vládních těles v prvních měsících roku 1945. V několika politických zprávách informoval Jaroslav Lípa své nadřízené o různých kandidátech na post regenta za monarchu, kterému bylo z rozhodnutí AVNOJ zakázán návrat do Jugoslávie až do definitivního vyřešení otázky jeho přítomnosti v zemi. Demonstrace proti králi Petrovi, ke kterým v zemi došlo po králově odvolání Ivana Šubašiće, Čechoslováci oprávněně považovali za zinscenované, jako prostředek nátlaku na krále i spojence, aby byli na místa regentů jmenováni kandidáti partyzánu․ ${ }^{66}$ Čechoslováci se dále zajímali i o možnosti prosazení starších politiků v nové domácí vládě, byli si ovšem vědomi toho, že jejich podíl na moci bude zanedbatelný ${ }^{67}$

Přiškrcování kontaktů s jugoslávskou královskou vládou dále pokračovalo. Na konci ledna 1945 přerušili Čechoslováci spojení, které Jugoslávcům poskytovali skrze Jaroslava Kopeckého v Ženevě. Povaha většiny vzkazů, které touto cestou putovaly, byla neslučitelná se zájmy Československa, které nadále nehodlalo podporovat proti Titovi zaměřené politiky. ${ }^{68}$ Osud těchto protikomunistických činitelů hodnotilo jisté memorandum pro prezidenta Beneše chmurně:

„Oposici, která se dnes tvoř́[,] neslibuji dlouhé trváni a význam. Neni mezi sebou jednotná a nemá mravni základy. Tím nechci ř́ci, že by všichni jeji členové byli špatnými lidmi. Jsou mezi nimi i lidé kvalifikovaní, zejména v posuzováni prostředi jihoslovanského. Jsou však jako nemocni. Nejsou př́stupni žádnému důvodu, ani vývoji. Jsou naplněni svým nepřátelstvím srbsko-chorvatským, tak že je pro ně hlavnim voditkem, Jsme ochotni přijati komunismus. Ale když, pak prijmeme komunismus př́mo z Moskvy a neni nám zapotřebi, abychom jej prijimali ze Záhřebu.

Je těžko říci, co tyto lidi čeká. Patrně se zapoji do světové reakce a společně s emigrací polskou, s nespokojenci slovenskými a snad jiných zemi budou středisky, nebo zárodky nových fašismů, nacismů a reakcí. A v tom je jejich nebezpeči. "

Autor dále uvádí, že mu několik vysokých důstojníků královské armády „učinilo dotaz, zda by mohli vstoupit do naši armády. Upozornil jsem na zákaz MNO přijímat cizince do naši armády vi̊bec. "69

65 Např. AMZV, f. LA-D, krab. 81, č. j. 1232/45, žádost o údaje k hospodářskému zpravodajství, 27. prosinec 1944 a řada dalších dokumentů tamtéž a v krab. 140T. Od poloviny roku výrazně ubylo zmínek o Jugoslávii v deníku Jana Opočenského: od května 1944 až do konce války se v něm zachovala jedna jediná letmá zmínka z 5. ř́ijna 1944. Čechurová, J. (a kol. edd.) - Opočenský, J.: Válečné deniky, s. 375.

66 AMZV, f. LA-D, krab. 81, č. j. 828/dův/45, zpráva o demonstracích v Jugoslávii z 18. ledna 1945.

67 AÚTGM, f. EB II, krab. 113, sign. V86/2, záznam z rozmluvy Huberta Ripky a Josefa Korbela s Vladimirem Velebitem, 13. prosince 1944. V. Velebit prohlásil, že „staři jugoslávští politikové jsou hotovi. Budou se moci vrátit domů a nějak se včlenit do veřejné administrativy. “

68 Předáváním dalších vzkazů by se Čechoslováci dle H. Ripky zaplétali do vnitřních jugoslávských sporů. AMZV, f. LA-D, krab. 140T, č. j. 1055/dův/45. Další zprávy ze Ženevy se po tomto datu již nevyskytují.

69 AÚTGM, f. EB II, krab. 454, memorandum bez uvedeného autora, založeno ad acta dne 26. ledna 1945. 
Čechoslováci uznali novou vládu v Jugoslávii bezprostředně poté, co byli o jejím ustavení oficiálně informováni V. Vilderem dne 13. března v dopisu Janu Masarykovi. ${ }^{70}$ Londýnské jugoslávské úřady nicméně s Čechoslováky také nadále komunikovaly, nebot na počátku března jmenovaly nového vojenského atašé, podplukovníka Danila Zobenicu. Čechoslováci jeho jmenování akceptovali. Zůstává zajímavým dokladem jisté setrvačnosti, nebo možná diplomatického taktu, že zprávy, které Jugoslávci Čechoslovákům v této věci zaslali, ale též československé odpovědi, byly nadále vedeny pod hlavičkou komunikace s „královskou jugoslávskou vládou. "71 V této době již probíhaly přípravy k přesunu československého vyslanectví zpět do Bělehradu. Vyslanec Jaroslav Lípa dorazil do hlavního města Jugoslávie dne 24. dubna $1945 .^{72}$

\section{Závěrem}

Jakkoliv přesun pozornosti „od krále k maršálovi“ v letech 1943-1945 může vyhlížet revolučně, československá exilová vláda jeho realizací vykonala politicky nevyhnutelný krok, který jasně souvisel jak s chronickou neschopností exilové vlády, tak s potenciálem partyzánského hnutí. A tak ačkoliv dosavadní styky s jugoslávskou exilovou vládou nebyly příliš plodné ${ }^{73}$ následující období, kdy se v otázkách poválečného uspořádání Jugoslávie dostalo ke slovu sílící partyzánské hnutí, přineslo jejich výrazný útlum. Odečteme-li informace o otázkách vzájemného poměru královské vlády a AVNOJ, zůstává z této doby pouze několik málo dokladů o stycích mezi exilovými Čechoslováky a Jugoslávci. S tím, jak klesala intenzita těchto jednání, narůstaly naopak kontakty s vládou působící přímo v zemi. Jisté množství zpráv z cizích zdrojů, ale také jednání, která s partyzánskými zástupci vedli sami Čechoslováci, mylně naznačovala také nechut partyzánů k poválečnému prosazování komunismu v Jugoslávii. Avšak ani zprávy svědčící o opaku Čechoslováky $\mathrm{k}$ důraznější podpoře exilové vlády a nekomunistických jugoslávských činitelů nepohnuly a ani pohnout nemohly. Jednota Jugoslávie se stabilní nomenklaturou v čele byla, jak je ostatně přirozené, pro československou vládu důležitější než vnitřní povaha režimu, který v ní měl panovat. Byla to naopak starší jugoslávská politická garnitura jako celek, kdo v očích svých dřívějších československých partnerů nyní znamenal hrozbu jednotě a národnostnímu smíru v nově se konstituující Jugoslávii. K této roli však exilovou vládu Království Jugoslávie nepředurčila pouze mocenská převaha jejích komunistických protivníků, ale též neslavná bilance jejích vlastních akcí. V průběhu války sílící rozkol

$\mathrm{S}$ ohledem $\mathrm{k}$ dalším poznámkám o názorech členů partyzánské mise v Londýně a vůbec důkladnému přehledu v názorech jednotlivých Jihoslovanů, lze jako jeho autora předpokládat Josefa Korbela, Huberta Ripku, možná i samotného Edvarda Beneše.

70 AMZV, f. LA, krab. 99/9, č. j. 9554/45, telegram Većeslava Vildera ministru zahraničí československé vlády ze dne 13. bř̀zna.

71 Tamtéz̆, č. j. 11037, zpráva o změně jugoslávského vojenského atašé z 26. března 1945.

72 Tamtéz, č. j. 4611/dův/45, zpráva z 25. dubna 1945 informující o př́ijezdu vyslance Lípy do Bělehradu dne 24. dubna 1945.

73 Pro jejich přehled viz Pospíchal, J.: Odtažitost, s. 451-502. 
ve vzájemných vztazích československé exilové vlády s těmito činiteli, reprezentanty dosavadního královského státního zřízení, časem přerostl v jejich úplný rozpad a konec.

\title{
From the King to the Marshal. The Epilogue of Contacts of Czechoslovak Government-in-Exile with the Royal Government- -in-Exile of Yugoslavia and the Beginnings of Its Cooperation with a Movement of J. B. Tito in 1943-1945
}

\begin{abstract}
Although the shift of focus of the Czechoslovak government-in-exile „from the king to the marshall“ (i. e. from Petar II. Karađorđević to J. B. Tito) between 1943-1945 might seem as a revolutionary act, its implementation has been an inevitable political step, clearly related to the chronical incompetence of the Yugoslav government-in-exile and also a strong potential of the Partyzan movement. And although the dealings between the Czechoslovak and Yugoslav exile governments so far have not been fruitful, the following period, during which the Partyzans dominated as a ruling force on the territory of Yugoslavia itslef, saw even greater diminishing of contacts between the two governments in exile. Apart from first-hand information about mutual relations between the Yugoslav émigrés and the Partyzans, only few testimonies of contacts between the Czechoslovaks and Yugoslavs in exile remain. Although the Czechoslovaks had proofs about communist orientation of the Partyzans, they have decided to cautiously support this new state power in Yugoslavia over the former, monarchistic politicians. The internal coherence and unity of Yugoslavia with a stable state power was naturally more important than the ideological nature of its internal régime. On the contrary, it was, for the Czechoslovaks, the former Yugoslav monarchist elite who now posed a threat to the unity and ethnic peace of the restored Yugoslav state. The Yugoslav government-in exile, however, ended up in this position not only because of the political and military supremacy of the Partyzans, but also because of its own poor performance. Czechoslovaks relations with these exiled politicians during the war gradually deteriorated and eventually ended.
\end{abstract}

